DIÁLOGO DE POETAS

\title{
María Baranda*
}

\section{(los niños/el verbo)}

Y todo cuanto he sido

regresa, como una gracia al verbo

y sin embargo

de víboras lodosas colgadas

en los ganchos, alisadas

atmósferas de sal,

residuos en los labios

de tantas las pobrezas,

cinco niños de níquel

tallados en mi cráneo,

veranos espumosos en el habla

y el miedo al cinturón

en el tanteo de qué

lejanas madres presas

que reverberan ofendidas

en la cal más tenebrosa,

cinco espejos ceñidos

en el hielo de la fría

desesperanza y los postigos

en el álamo, cáliz al vértigo

de nuestras lenguas,

sustanciales suicidios

más hermosos que la luz

de una caja vacía,

todo coincide y frasea

en su propia fragilidad,

se desescucha

* Todos los poemas pertenecen al libro Medusa \& Co. de próxima publicación. 


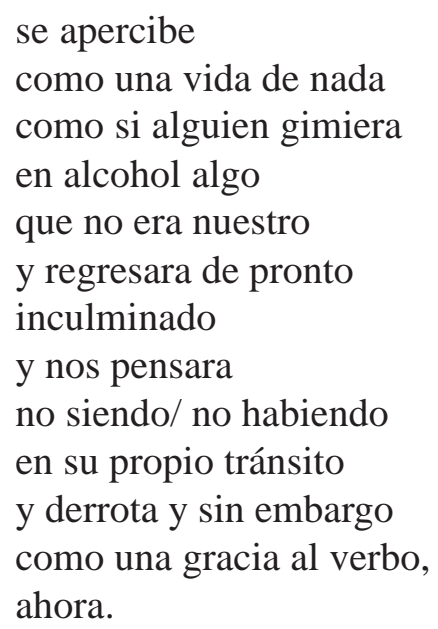

\section{(los bulbos/ la tierra)}

Crece el dióxido en mí, me ocupa tanta -me sulfuratoma de sí el aire y se compone de/ en ese momento ah/ números, cúmulos, gránulos todo en un cuadro vital donde se absorbe místicamente en la garganta -échale, pónelejarras y jarras celestes:

Padre/Madre:

háganme salir al vuelo

volado de mi lengua en el inicio y el candor

de un cáliz cálido que calla y

"todo se va, María, ten calma."

Y luego, niña, elude. Elude, que únicamente el verde así provoca vida parasiempre.

- Ah- 